
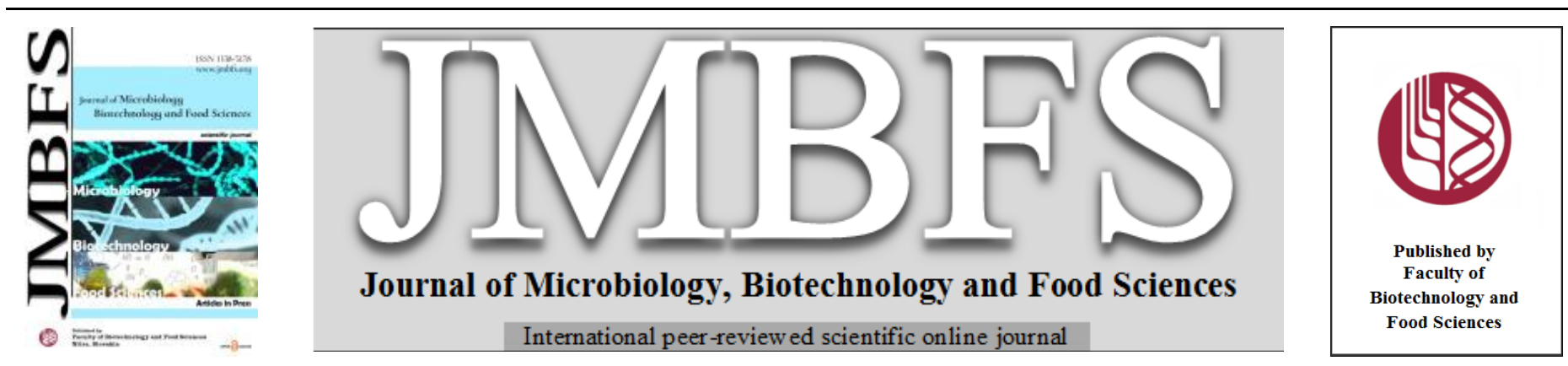

\title{
KINETIC MODEL OF COMMERCIAL GLUCOSE-AFFECTED GROWTH AND MICROBIAL OIL PRODUCTION OF OLEAGINOUS YEAST Pseudozyma parantarctica CHC28
}

\author{
Atsadawut Areesirisuk ${ }^{* 1,2}$, Jantima Teeka ${ }^{1,2}$, Chutima Rakkitkanphun ${ }^{1}$, Sunanta Bunmadee ${ }^{1}$, Thidarat Samranrit ${ }^{l}$, Sasitorn \\ Khunthong ${ }^{1}$, Dolnapa Kaewpa ${ }^{1}$, Apinan Wanlapa ${ }^{3}$
}

Address (es):

${ }^{1}$ Division of Biology, Faculty of Science and Technology, Rajamangala University of Technology Thanyaburi, Khlong Luang, 12110 Pathum Thani, Thailand, (+66)25494177.

${ }^{2}$ Center of Excellence in Nano-Biotechnology, Faculty of Science and Technology, Rajamangala University of Technology Thanyaburi, Khlong Luang, 12110 Pathum Thani, Thailand. (+66)2-5494142.

${ }^{3}$ Division of Food Engineering, Faculty of Engineering, Rajamangala University of Technology Thanyaburi, Khlong Luang, 12110 Pathum Thani, Thailand. (+66)25493581 .

*Corresponding author: atsadawut_a@rmutt.ac.th

https://doi.org/10.15414/jmbfs.4080

\section{ARTICLE INFO}

Received 13. 12. 2020

Revised 1. 7. 2021

Accepted 12. 7. 2021

Published 1. 12. 2021

Regular article OPEN $\partial_{\text {AcCESS }}$

\begin{abstract}
This research proposed to study the effect of commercial glucose concentration in a nitrogen-limiting medium on the growth of Pseudozyma parantarctica $\mathrm{CHC} 28$ and to estimate the kinetic parameters of fermentation. The biomass, microbial oil, biomass production rate $\left(Q_{\mathrm{x}}\right)$, and oil production rate $\left(Q_{\mathrm{p}}\right)$ increased dramatically and reached $22.10 \pm 1.95 \mathrm{~g} / \mathrm{L}, 10.99 \pm 1.31 \mathrm{~g} / \mathrm{L}$, $0.184 \pm 0.016 \mathrm{~g} / \mathrm{L} \mathrm{h}$, and $0.092 \pm 0.011 \mathrm{~g} / \mathrm{L} \mathrm{h}$, respectively, when glucose concentration was increased to $100 \mathrm{~g} / \mathrm{L}(\mathrm{C} / \mathrm{N}$ ratio $=333)$. In contrast, these results showed a decrease when glucose and $\mathrm{C} / \mathrm{N}$ ratio were higher than $100 \mathrm{~g} / \mathrm{L}$ and 333, respectively. Concurrently, the oil content showed a continuous rise as the glucose and $\mathrm{C} / \mathrm{N}$ ratio increased. Furthermore, the maximum specific growth rate $\left(\mu_{\max }\right)$ declined sharply when $P$. parantarctica was cultivated under high glucose concentration. It was therefore suggested that the glucose concentration could affect the growth of oleaginous yeast because of osmotic pressure and $\mathrm{C} / \mathrm{N}$ ratio. For the bioreactor scale, biomass, microbial oil, and oil content were enhanced to $29.92 \mathrm{~g} / \mathrm{L}, 15.13 \mathrm{~g} / \mathrm{L}$, and $50.57 \% \mathrm{w} / \mathrm{w}$, respectively, at $120 \mathrm{hrs}$ of cultivation. The mathematical models could describe the effect of glucose concentration on both yeast growth and microbial oil production. Thus, the kinetic model satisfactorily fitted the experimental data relating to oleaginous growth, microbial oil production, and substrate consumption.
\end{abstract}

Keywords: oleaginous yeast, microbial oil, glucose-affected growth, kinetic model

\section{INTRODUCTION}

The energy crisis is one of the most critical issues in current times. Due to the limited reserves of fossil fuels, high energy demand, and environmental impact, meeting the future energy demand is a matter of great concern (Ma et al., 2018). Renewable energy has emerged as one of the most feasible solutions to overcome this challenge. Biodiesel obtained from energy crops and their derivatives reduces undesirable effects on the environment, such as acid rain and the greenhouse effect caused by fossil fuel combustion. In addition, it offers an advantage over fossil fuels because it is biodegradable and renewable (Soccol $\boldsymbol{e} t$ al., 2017). However, the amount of vegetable oils available for biodiesel production is insufficient in case of increase in demand. Currently, single-cell oil or microbial oil has been reported to be a fascinating alternative source for biodiesel production. The cultivation of microorganisms producing microbial oil can be carried out through an uncomplicated process with low-cost raw materials. The microorganism which accumulates more than 20 percent of intracellular oil is identified as an oleaginous microorganism (Qin et al., 2017). The various oleaginous microorganisms which can produce microbial oil include bacteria, yeasts, molds, and microalgae (Qasim and Sultan, 2020; Saenge et al., 2011). Previous research has shown that yeast has an advantage over other oleaginous microorganisms, in growing and producing oil at a higher rate (Saenge et al., 2011). The fatty acid compositions of yeasts are similar to that of vegetable oils such as palm, coconut, jatropha, and rapeseed oils (Ong et al., 2011; Satyanarayana and Muraleedharan, 2011; Areesirisuk et al., 2015; Sutanto et al., 2018). Oleaginous yeast is cultured in order to extract intracellular oil from microbial cells. The microbial oils thus obtained are used as a feedstock for biodiesel production, thus offering an interesting alternative (Li et al., 2007).

Previous research has found that oleaginous microorganisms could be induced to produce and accumulate oil in media containing an excess of carbon, with limitation in the quantities of some elements such as phosphorus, sulfate, or nitrogen (Gill et al., 1977; Jakobsen et al., 2008; Wu et al., 2010, 2011; Bonturi et al., 2017). For instance, phosphorus is an important component of microbial growth. It is used to determine the composition of biomolecules, i.e., nucleic acid, phospholipids, and coenzymes. Studies show that phosphate limitation could lead to oil production in oleaginous yeast (Granger et al., 1993; Wu et al., 2010). Further, nitrogen deficiency was also proposed as a master regulator of oil synthesis (Ratledge and Wynn, 2002; Bonturi et al., 2017). Moreover, it has been observed that the application of nitrogen starvation strategy in microbial oil production, provides higher intracellular oil content when compared to oil content generated by the limitation of other elements (Wu et al., 2010).

In this context, a mathematical model of the microbial fermentation process may be applied to understand and predict the fermentation profile. Moreover, such models could be used to estimate the kinetic parameters of fermentation. For instance, a practical model could be used to at least indicate parameters such as microbial growth, substrate consumption, and characteristics of product formation during fermentation (Yang et al., 2011; Farias et al., 2014).

Therefore, given all of the above-mentioned factors, in this study, kinetic modeling was used to evaluate the effect of glucose-based nitrogen-limiting media on growth, microbial oil production, and substrate consumption of oleaginous yeast Pseudozyma parantarctica $\mathrm{CHC} 28$. This research aimed to study the influence of commercial glucose concentration on the growth of oleaginous yeast and to employ a mathematical model for predicting yeast growth and microbial oil production profiles. 


\section{MATERIALS AND METHODS}

\section{Yeast strain and inoculum preparation}

$P$. parantarctica $\mathrm{CHC} 28$, an oleaginous yeast, was used in this study (Areesirisuk et al., 2015). The stock culture of oleaginous yeast $\mathrm{CHC} 28$ was recultured in Yeast Malt broth (YM broth) at $30^{\circ} \mathrm{C}, 150 \mathrm{rpm}$ of shaking speed, for $24 \mathrm{hrs}$. Subsequently, $5 \mathrm{~mL}$ volume of activated yeast (with an optical density of approximately $0.7-0.8$ at $600 \mathrm{~nm}$ ) culture was transferred to a $100 \mathrm{~mL}$ seed medium containing (in g/L): glucose 20, yeast extract $0.5,\left(\mathrm{NH}_{4}\right)_{2} \mathrm{SO}_{4} \quad 5.0$, $\mathrm{MgSO}_{4} \cdot 7 \mathrm{H}_{2} \mathrm{O} 0.5$, and $\mathrm{KH}_{2} \mathrm{PO}_{4}$ 1.0. It was cultured as per the above-mentioned procedure for $20 \mathrm{hrs}$. This cultured yeast was used as a starter in the following experiment

\section{Glucose-affected growth of oleaginous yeast}

Five milliliters of yeast starter were aseptically inoculated into $100 \mathrm{~mL}$ of nitrogen-limiting medium containing (in g/L): yeast extract $0.1,\left(\mathrm{NH}_{4}\right)_{2} \mathrm{SO}_{4} 0.5$ $\mathrm{MgSO}_{4} \cdot 7 \mathrm{H}_{2} \mathrm{O} \quad 0.15$, and $\mathrm{KH}_{2} \mathrm{PO}_{4}$ 7.0. Commercial glucose produced from cassava starch (cassava starch-based glucose, WGC, Co. Ltd.) was used as the primary carbon source. This glucose was added as the sole carbon source and its concentration was varied between 20 to $300 \mathrm{~g} / \mathrm{L}$. The batch fermentation was performed at $30^{\circ} \mathrm{C}$ and $150 \mathrm{rpm}$ of shaking speed. The culture was withdrawn aseptically from the experimental flask and the biomass, oil, and glucose concentration were determined as described below. The experiments were run in triplicates.

The bioreactor scale experiment was performed using $5 \mathrm{~L}$ of nitrogen-limiting medium containing glucose $100 \mathrm{~g} / \mathrm{L}$ in a 10-L fermenter (Major Science, MS-F1, Taiwan). Fifteen milliliters of the re-cultured oleaginous strain were aseptically transferred to $300 \mathrm{~mL}$ of seed medium and cultured at $30^{\circ} \mathrm{C}$ and $150 \mathrm{rpm}$ o shaking speed for $20 \mathrm{hrs}$. Five hundred milliliters of seed culture were aseptically inoculated to the bioreactor and cultivated at $30^{\circ} \mathrm{C}$, a stirring speed of $300 \mathrm{rpm}$, and $1.0 \mathrm{vvm}$ of aeration rate. The sample was withdrawn throughout cultivation to determine glucose, biomass, and oil concentration.

\section{Analytical method}

The yeast cells were harvested by centrifugation at $12,000 \mathrm{rpm}$ for $10 \mathrm{~min}$ and washed twice with water. The cleaned cells were dried at $60^{\circ} \mathrm{C}$ to a constant weight, usually for $24 \mathrm{hrs}$. The biomass was determined gravimetrically and expressed as the gram of biomass per liter (Xue et al., 2008). The oil concentration was analyzed with a mixture of chloroform and methanol, according to the method proposed in Bligh and Dyer (1959). Glucose was determined using 3,5-dinitrosalicylic colorimetric method (Miller, 1959).

\section{Kinetic model}

The growth rate of oleaginous yeast was investigated by the Logistic equation in (1) (Zajšek and Goršek, 2010; Laopaiboon et al., 2016), as follows:

$\frac{d X}{d t}=\mu_{\max } X\left(1-\frac{X}{X_{\max }}\right)$

where $\mu_{\max }$ was the maximum specific growth rate, $X$ was the biomass at specific times $(t)$ of yeast growth, and $X_{\max }$ was maximum biomass concentration.

The rate of substrate consumed ( $d S / d t)$ was used to explain the cell growth rate (including the intracellular oil) and the biomass concentration following the equation (2):

$\frac{d S}{d t}=\frac{1}{Y_{\mathrm{x} / \mathrm{s}}}\left(\frac{d X}{d t}\right)+m_{\mathrm{s}}$

where $Y_{\mathrm{x} / \mathrm{s}}$ was the biomass yield on substrate and $m_{\mathrm{s}}$ was the biomass maintenance coefficient. The rate of production of oil $(d P / d t)$ was dependent on the biomass concentration, following the Luedeking-Piret equation given below:

$\frac{d P}{d t}=\alpha \frac{d X}{d t}+\beta X$

In Eq. (3) $\alpha$ was a growth-associated oil formation coefficient, and $\beta$ was a nongrowth-associated oil formation coefficient. If $\alpha \neq 0$ and $\beta=0$, the oil formation was directly coordinated to microbial growth; if $\alpha \neq 0$ and $\beta \neq 0$, the oil formation was partially dependent on microbial growth; and if $\alpha=0$ and $\beta \neq 0$, the oil formation was unrelated to microbial growth (Gaden, 2000; Yang et al., 2011).

\section{Estimation of model parameters}

The kinetic parameters of the Logistic model $\left(\mu_{\max }\right.$ and $\left.X_{\max }\right)$ were calculated to fit the model and the experimental data. The fitting was performed using Berkley Madonna ${ }^{\mathrm{TM}}$ software for curve fitting (Marudkla et al., 2018). The coefficient of determination $\left(R^{2}\right)$ was applied to measure the model fitting quality between the predicted and the experimental data (Wannawilai and Sirisansaneeyakul, 2015). $R^{2}$ was calculated using the following equation:

$R^{2}=\frac{\sum\left(C_{\text {pred }}-\bar{C}_{\text {exp }}\right)^{2}}{\sum\left(C_{\text {pred }}-\bar{C}_{\text {exp }}\right)^{2}+\sum\left(C_{\text {pred }}-C_{\text {exp }}\right)^{2}}$

In Eq. (4), $C_{\text {pred }}$ was the value of a predicted variable using the mathematical model. $C_{\exp }$ and $\bar{C}_{\exp }$ were the corresponding experimental values and the average of all the experimented values of the critical variable, respectively. The nonnormalized root means square $(N R M S)$ value was employed to investigate the actual error for each determination (Wannawilai and Sirisansaneeyakul, 2015) The NRMS was expressed as follows:

$N R M S=\sqrt{\frac{\sum_{\mathrm{i}=1}^{N}\left(C_{\mathrm{cal}}-C_{\mathrm{exp}}\right)^{2}}{N}}$

where $N$ is the number of determinations.

\section{Statistical method}

The experimental data were examined for statistical significance using a one-way analysis of variance (ANOVA). Duncan's multiple range test (DMRT) was used to compare the effect of glucose on fermentation parameters. Statistical analysis was performed using SPSS 15.0 software (SPSS Inc., USA).

\section{RESULTS AND DISCUSSION}

\section{Glucose-affected growth and oil production of oleaginous yeast}

The glucose-affected growth of $P$. parantarctica $\mathrm{CHC} 28$ was studied. The batch fermentations were operated in a shaking flask with glucose variation between 20 $\mathrm{g} / \mathrm{L}$ and $300 \mathrm{~g} / \mathrm{L}$. Figure 1 represents the biomass concentration of $P$. parantarctica $\mathrm{CHC} 28$ against cultivation time. The results showed that the growth of $P$. parantarctica $\mathrm{CHC} 28$ was affected by glucose concentration as the primary carbon source. The yeast growth increased with an increase in glucose and then decreased slightly when glucose was increased to $120 \mathrm{~g} / \mathrm{L}$. This result suggested that $P$. parantarctica $\mathrm{CHC} 28$ could grow well without substrate inhibition under a wide range of substrate concentrations, especially from 20 to $100 \mathrm{~g} / \mathrm{L}$

Table 1 presents the microbial oil production of yeast following $120 \mathrm{hrs}$ of cultivation. The biomass and oil production were enhanced following the increase in the glucose concentration until $100 \mathrm{~g} / \mathrm{L}$. Subsequently, they clearly dropped when yeast was cultured in glucose over $100 \mathrm{~g} / \mathrm{L}$. The oil conten increased continuously in accordance with the increasing $\mathrm{C} / \mathrm{N}$ ratio, and the maximum oil content of $59.70 \pm 2.51 \%$ was obtained at $300 \mathrm{~g} / \mathrm{L}$ of glucose $(\mathrm{C} / \mathrm{N}$ ratio $=999)$. Simultaneously, the biomass production rate $\left(Q_{\mathrm{x}}\right)$ and oil production rate $\left(Q_{\mathrm{p}}\right)$ rapidly reached the highest values of $0.190 \pm 0.019$ and $0.092 \pm 0.011 \mathrm{~g} / \mathrm{L}$ at glucose levels of 80 and $100 \mathrm{~g} / \mathrm{L}$, respectively. Furthermore, the $Q_{\mathrm{x}}$ and $Q_{\mathrm{P}}$ reduced dramatically when glucose was higher than $100 \mathrm{~g} / \mathrm{L}$. Thus, it was found that when $P$. parantractica $\mathrm{CHC} 28$ was cultured in glucose $100 \mathrm{~g} / \mathrm{L}(\mathrm{C} / \mathrm{N}$ ratio $=$ 333 ), it produced the maximum biomass, oil, $Q_{\mathrm{x}}$, and $Q_{\mathrm{p}}$, at the rate of $22.10 \pm 1.95 \mathrm{~g} / \mathrm{L}, 10.99 \pm 1.31 \mathrm{~g} / \mathrm{L}, 0.184 \pm 0.016 \mathrm{~g} / \mathrm{L} \mathrm{h}$, and $0.092 \pm 0.011 \mathrm{~g} / \mathrm{L} \mathrm{h}$, respectively. These results suggested that oil accumulation occurred most frequently, when the nutrient source, particularly the nitrogen source, was limited, while the excess carbon source was offered at the required levels (Bonturi et al., 2017). Typically, it occurred concurrently with the stationary phase. Thus, nitrogen limitation has proved to be one of the most practical methods to induce oil production because it can easily control media composition. Eventually, oil synthesis pathways of microorganisms were positively regulated to balance cell growth with energy storage (Beopoulos $\boldsymbol{e t}$ al., 2009; Tai and Stephanopoulos, 2013). Also, earlier studies have also supported the well-known fact that optimum $\mathrm{C} / \mathrm{N}$ ratio can repress Kreb's cycle performance and accumulate citric acid for microbial oil synthesis (Huang et al. 2016) 

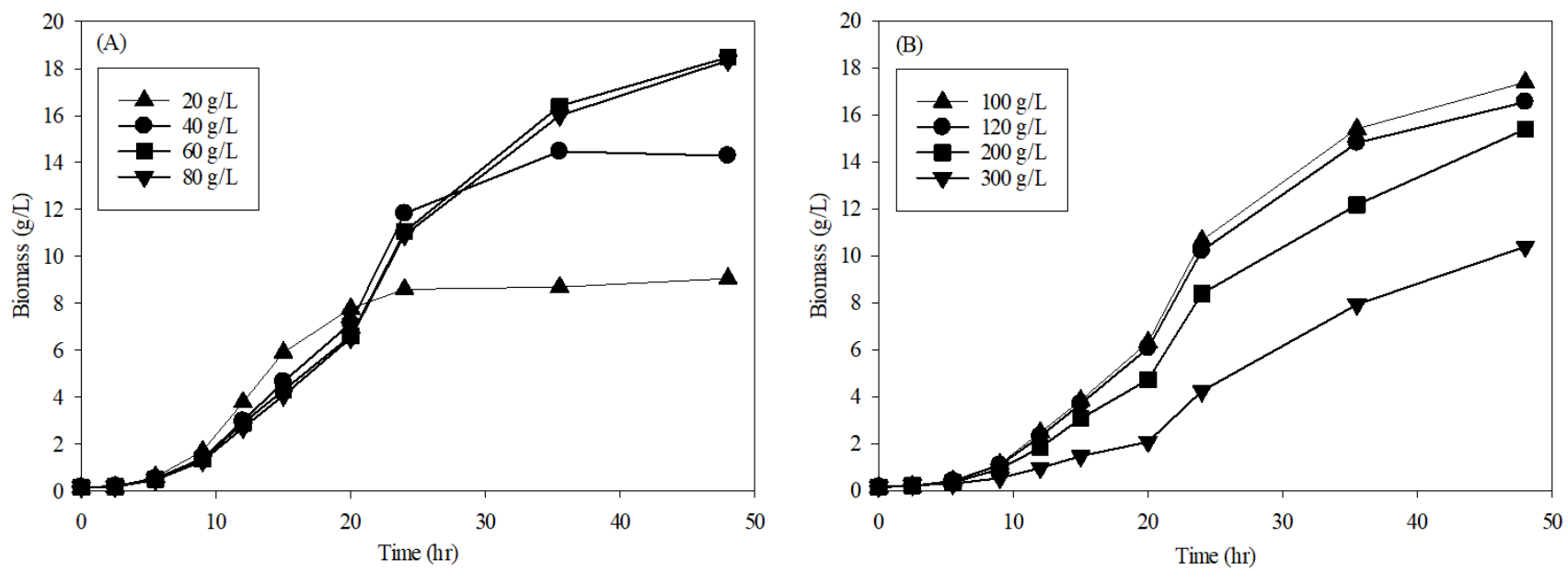

Figure 1 Biomass growth during fermentation in the glucose-based nitrogen-limiting medium. The initial glucose concentrations were (A) $20-80 \mathrm{~g} / \mathrm{L}$ and (B) $100-300 \mathrm{~g} / \mathrm{L}$

Table 1 Effect of initial glucose concentration on biomass, oil, oil content, biomass production rate, and oil production rate of $P$. parantarctica at $120 \mathrm{hrs}$ of cultivation

\begin{tabular}{ccccccc}
\hline Glucose $(\mathbf{g} / \mathbf{L})$ & C/N ratio & Biomass $(\mathbf{g} / \mathbf{L})$ & Oil $(\mathbf{g} / \mathbf{L})$ & Oil content $(\% \mathbf{w} / \mathbf{w})$ & $\boldsymbol{Q x}(\mathbf{g} / \mathbf{L} \mathbf{h})$ & $\boldsymbol{Q p}(\mathbf{g} / \mathbf{L} \mathbf{~ h})$ \\
\hline 20 & 67 & $9.11 \pm 0.33 \mathrm{~d}$ & $1.09 \pm 0.31 \mathrm{e}$ & $11.83 \pm 3.04 \mathrm{f}$ & $0.076 \pm 0.003 \mathrm{~d}$ & $0.009 \pm 0.003 \mathrm{e}$ \\
\hline 40 & 133 & $15.24 \pm 0.10 \mathrm{c}$ & $3.43 \pm 0.43 \mathrm{~d}$ & $22.52 \pm 2.81 \mathrm{e}$ & $0.127 \pm 0.001 \mathrm{c}$ & $0.029 \pm 0.004 \mathrm{~d}$ \\
\hline 60 & 200 & $21.02 \pm 0.12 \mathrm{ab}$ & $6.96 \pm 0.49 \mathrm{c}$ & $33.10 \pm 2.17 \mathrm{~d}$ & $0.175 \pm 0.001 \mathrm{ab}$ & $0.058 \pm 0.004 \mathrm{c}$ \\
\hline 80 & 267 & $22.85 \pm 2.28 \mathrm{a}$ & $9.34 \pm 1.17 \mathrm{ab}$ & $41.48 \pm 9.24 \mathrm{c}$ & $0.190 \pm 0.019 \mathrm{a}$ & $0.078 \pm 0.010 \mathrm{~b}$ \\
\hline 100 & 333 & $22.10 \pm 1.95 \mathrm{ab}$ & $10.99 \pm 1.31 \mathrm{a}$ & $49.64 \pm 1.54 \mathrm{~b}$ & $0.184 \pm 0.016 \mathrm{ab}$ & $0.092 \pm 0.011 \mathrm{a}$ \\
\hline 120 & 400 & $20.27 \pm 1.68 \mathrm{~b}$ & $9.78 \pm 1.74 \mathrm{ab}$ & $48.03 \pm 4.83 \mathrm{bc}$ & $0.169 \pm 0.014 \mathrm{~b}$ & $0.082 \pm 0.015 \mathrm{ab}$ \\
\hline 200 & 666 & $17.15 \pm 0.12 \mathrm{c}$ & $8.78 \pm 0.08 \mathrm{~b}$ & $51.21 \pm 0.66 \mathrm{~b}$ & $0.143 \pm 0.001 \mathrm{c}$ & $0.073 \pm 0.001 \mathrm{~b}$ \\
\hline 300 & 999 & $9.80 \pm 0.51 \mathrm{~d}$ & $5.84 \pm 0.08 \mathrm{c}$ & $59.70 \pm 2.51 \mathrm{a}$ & $0.082 \pm 0.004 \mathrm{~d}$ & $0.049 \pm 0.001 \mathrm{c}$
\end{tabular}

Legend: The data indicate mean \pm standard deviation (SD). The different letters alongside the values in the same column indicate significant differences $(p-$ value $<0.05)$.

\section{Modeling the growth kinetic}

A growth kinetic model was used to predict the behavior of the microbial cultivation process. Equation (1) was deployed to model the biomass growth in nitrogen-limiting media, which contained glucose as the major carbon source. During cultivation, the lag phase was observed during 6-11 hours of fermentation. Subsequently, the $P$. paranrarctica $\mathrm{CHC} 28$ presented a classical growth trend corresponding to the sigmoid curve. Moreover, it was found that the final biomass concentration also depended on the initial glucose concentration. At the end of fermentation, the microbial oil was produced at an increasing rate when the initial substrate was enhanced to $100 \mathrm{~g} / \mathrm{L}$ and decreased slightly when glucose levels were raised higher than $120 \mathrm{~g} / \mathrm{L}$.

As shown in figures $2 \mathrm{~A}-2 \mathrm{H}$, the Logistic model fitted the experimental data wel (determination coefficients $\left(R^{2}\right) \geq 0.9907$ and $N R M S \leq 0.4920$ ). The biomass of P. parantarctica CHC28 could be satisfactorily modeled. As can be seen, the $R^{2}$ values obtained from the Logistic model were very high. All $R^{2}$ values were higher than 0.99. This result demonstrated that the Logistic model was suitable for describing the experimental biomass profile. However, it should be noted carefully that the Logistic equation could not explain the lag time and maximum biomass productivity.

Further, the Logistic model is ideal for estimating the growth kinetics, i.e., the maximum specific growth rate $\left(\mu_{\max }, \mathrm{h}^{-1}\right)$ (Phukoetphim et al., 2017). Table 2 shows the kinetic values in the Logistic model. The $\mu_{\max }$ was used to define the glucose-affected growth of $P$. parantarctica $\mathrm{CHC} 28$. It revealed that the highest $\mu_{\max }$ was obtained by using glucose $20 \mathrm{~g} / \mathrm{L}$ for $0.333 \pm 0.022 \mathrm{~h}^{-1}$. Subsequently, the $\mu_{\max }$ decreased dramatically upon cultivation in the nitrogen-limiting medium containing high initial glucose concentration, though the $\mu_{\max }$ of yeast cultivated in glucose $60-120 \mathrm{~g} / \mathrm{L}$ was not significantly different $(p$-value $<0.05)$. The cultivation of $P$. parantarctica in glucose $300 \mathrm{~g} / \mathrm{L}$ provided the lowest $\mu_{\max }$ for $0.146 \pm 0.004 \mathrm{~h}^{-1}$. These results suggested that glucose concentration and $\mathrm{C} / \mathrm{N}$ ratio could affect oleaginous yeast growth because of osmotic pressure.

Table 2 The kinetic values in the Logistic model of glucose-affected growth of oleaginous yeast $P$. parantarctica $\mathrm{CHC} 28$

\begin{tabular}{ccccc}
\hline Glucose $(\mathbf{g} / \mathbf{L})$ & $\boldsymbol{\mu}_{\max }\left(\mathbf{h}^{-1}\right)$ & $\boldsymbol{X}_{\max }(\mathbf{g} / \mathbf{L})$ & $\boldsymbol{R}^{\mathbf{2}}$ & NRMS \\
\hline 20 & $0.333 \pm 0.022 \mathrm{a}$ & $8.81 \pm 0.19 \mathrm{e}$ & 0.9985 & 0.1360 \\
\hline 40 & $0.223 \pm 0.005 \mathrm{~b}$ & $15.31 \pm 1.18 \mathrm{c}$ & 0.9929 & 0.4638 \\
\hline 60 & $0.178 \pm 0.003 \mathrm{c}$ & $18.41 \pm 0.20 \mathrm{a}$ & 0.9962 & 0.3960 \\
\hline 80 & $0.180 \pm 0.002 \mathrm{c}$ & $18.15 \pm 0.16 \mathrm{a}$ & 0.9961 & 0.3972 \\
\hline 100 & $0.189 \pm 0.004 \mathrm{c}$ & $17.19 \pm 0.25 \mathrm{~b}$ & 0.9964 & 0.3647 \\
\hline 120 & $0.192 \pm 0.006 \mathrm{c}$ & $16.39 \pm 0.44 \mathrm{~b}$ & 0.9968 & 0.3299 \\
\hline 200 & $0.161 \pm 0.002 \mathrm{~d}$ & $15.17 \pm 0.01 \mathrm{c}$ & 0.9907 & 0.4920 \\
\hline 300 & $0.146 \pm 0.004 \mathrm{e}$ & $10.93 \pm 0.56 \mathrm{~d}$ & 0.9963 & 0.2061 \\
\hline
\end{tabular}

Legend: The data indicate mean \pm standard deviation (SD). The different letters alongside the values in the same column indicate significant differences $(p$-value $<0.05)$. 

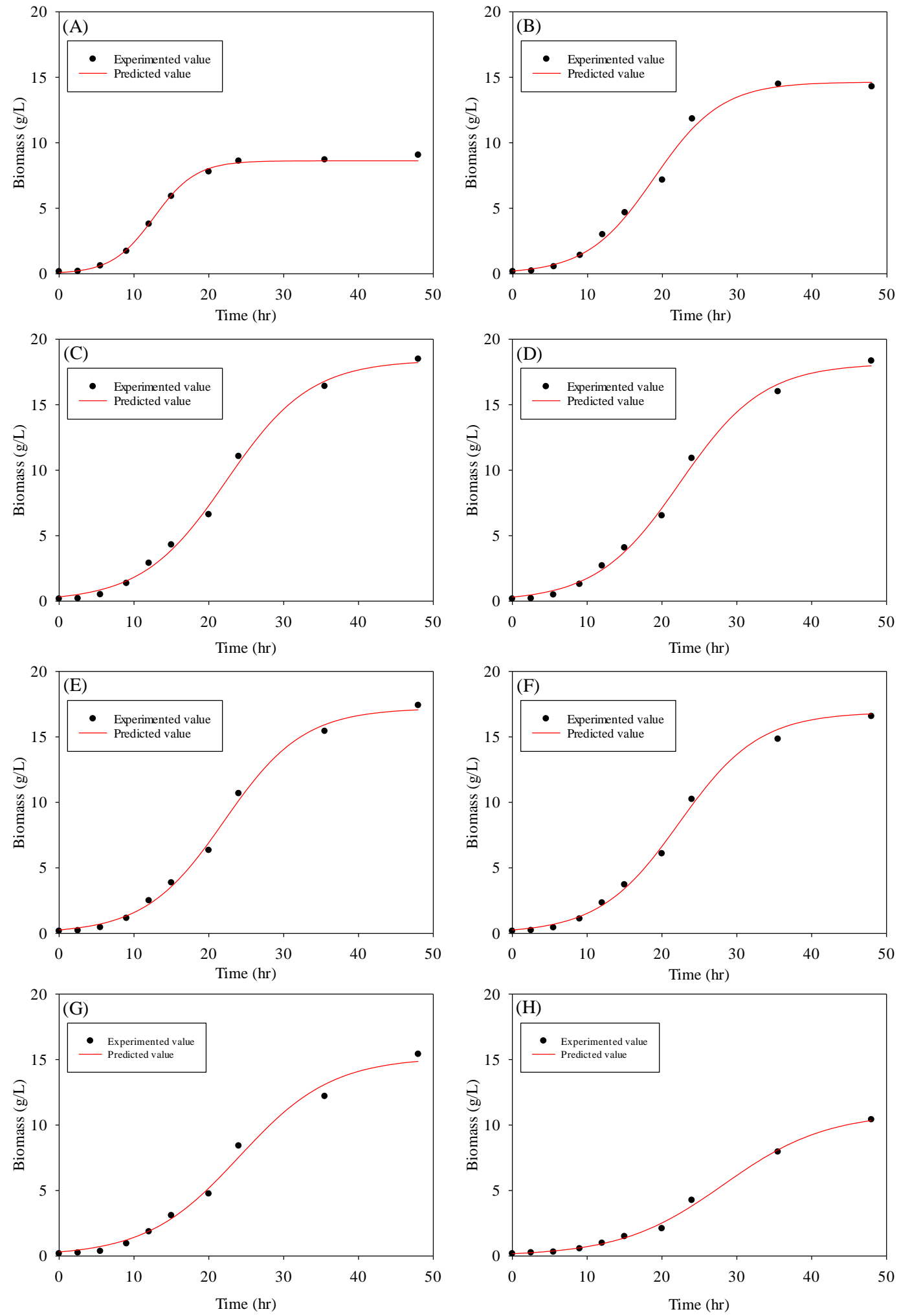

Figure 2 The experimental values (symbols) and model predictions (lines) of biomass concentration in the flask scale. Glucose-based medium with following initial concentrations of : (A) $20 \mathrm{~g} / \mathrm{L}$; (B) $40 \mathrm{~g} / \mathrm{L}$; (C) $60 \mathrm{~g} / \mathrm{L}$; (D) $80 \mathrm{~g} / \mathrm{L}$; (E) $100 \mathrm{~g} / \mathrm{L}$; (F) $120 \mathrm{~g} / \mathrm{L}$; (G) $200 \mathrm{~g} / \mathrm{L}$; (H) $300 \mathrm{~g} / \mathrm{L}$.

\section{Scale-up of microbial oil production in bioreactor and its kinetic modeling}

The fermentation profile of oleaginous yeast in a bioreactor (glucose $100 \mathrm{~g} / \mathrm{L}$, $\mathrm{C} / \mathrm{N}$ ratio $=0.333$ ) was illustrated in figure 3 . The lag time was verified using the online DMFit software (http://browser.combase.cc/DMFit.aspx) to fit a curve to the experimental biomass value. The result presented a lag phase of $8.14 \mathrm{hrs}$, which was shorter than that in a flask scale experiment $(9.65 \mathrm{hrs}$ for glucose 100 $\mathrm{g} / \mathrm{L}$ ), following which it entered the $\log$ and stationary phase. The maximum biomass was provided at $18.96 \mathrm{~g} / \mathrm{L}$ for $48 \mathrm{hrs}$, which was higher than that in the flask scale $(17.19 \mathrm{~g} / \mathrm{L})$. Besides, at $120 \mathrm{hrs}$ of cultivation, the biomass and oil levels reached $29.92 \mathrm{~g} / \mathrm{L}$ and $15.13 \mathrm{~g} / \mathrm{L}$, respectively. At the same time, the intracellular oil accumulation reached $50.57 \% \mathrm{w} / \mathrm{w}$. A comparison of the growth rate and oil production efficiency demonstrated that the biomass, oil, and oil content in the bioreactor scale were higher than those in the flask scale. The cause for this difference may be aeration. Previous studies have reported the influence of different aeration supplies in flask and bioreactor scale experiments on oleaginous yeast growth and microbial oil production (Yen and Zhang, 2011; Yen and Liu, 2014; Karamerou et al., 2016). It was demonstrated that the growth and oil yield of Rhodotorula glutinis showed an apparent increase in baffled bioreactor compared with a non-baffled bioreactor, indicating that air 
supply plays a key role in the growth of $R$. glutinis. However, when the aeration rate was increased higher than $0.5 \mathrm{~L} / \mathrm{min}$, the cell and oil concentrations were reduced. According to these findings, higher aeration did not improve growth or oil production. Although the impacts of aeration rates are still unclear, the size of air bubbles in the bioreactor might be a possible influencing factor. Higher airflow rates produce larger air bubbles with a smaller specific surface area, resulting in less oxygen mass transfer (Karamerou $\boldsymbol{e t}$ al., 2016). However, the effect of oxygen supply on the growth and oil production of $P$. parantarctica $\mathrm{CHC} 28$ should be further investigated.

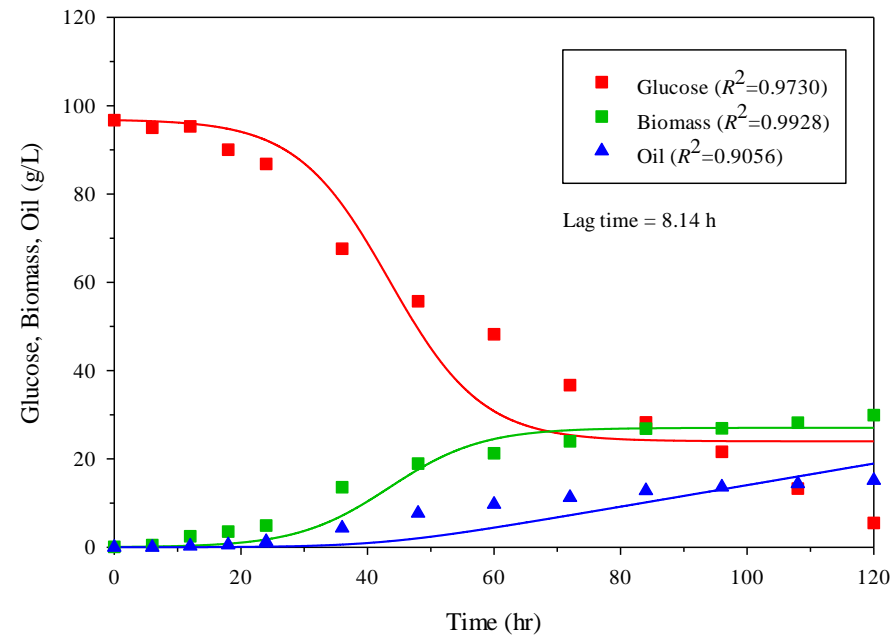

Figure 3 The experimental values (symbols) and model predictions (lines) of glucose, biomass, and oil concentration during fermentation with $5 \mathrm{~L}$ nitrogenlimiting medium containing glucose $100 \mathrm{~g} / \mathrm{L}$ in a bioreactor.

The values of the best-fit model parameters (i.e., $\mu_{\max }, X_{\max }, Y_{\mathrm{x} / \mathrm{s}}, m_{\mathrm{s}}, \alpha$, and $\beta$ ) in the bioreactor were shown in Table 3 . The $\mu_{\max }$ was $0.137 \mathrm{~h}^{-1}$, which is lower than the flask scale. However, the $X_{\max }$ was higher than the shaking flask scale (27.03 $\mathrm{g} / \mathrm{L}$ ). The $m_{\mathrm{s}}$ value was nearly zero, indicating that the almost substrate was used to form the oleaginous biomass, which was higher than that used for cell maintenance. The $\alpha$ and $\beta$ were very similar, which demonstrated that the oil production of $P$. parantarctica $\mathrm{CHC} 28$ was partially dependent on microbial growth (Yang et al., 2011).

Table 3 The model-estimated fermentation parameters in a bioreactor

\begin{tabular}{|c|c|c|}
\hline Model equations & Parameters & Values \\
\hline \multirow[t]{4}{*}{$\frac{d X}{d t}=\mu_{\max } X\left(1-\frac{X}{X_{\max }}\right)$} & $\mu_{\max }\left(\mathrm{h}^{-1}\right)$ & 0.137 \\
\hline & $X_{\max }(\mathrm{g} / \mathrm{L})$ & 27.03 \\
\hline & $R^{2}$ & 0.9928 \\
\hline & $N R M S$ & 0.3287 \\
\hline \multirow[t]{4}{*}{$\frac{d S}{d t}=-\left[\left(\frac{1}{Y_{\mathrm{x} / \mathrm{s}}}\right)\left(\frac{d X}{d t}\right)+m_{\mathrm{S}} X\right]$} & $Y_{\mathrm{x} / \mathrm{s}}$ & 0.37 \\
\hline & $m_{\mathrm{s}}(\mathrm{g} / \mathrm{g} \mathrm{h})$ & $3.12 \times 10^{-10}$ \\
\hline & $R^{2}$ & 0.9730 \\
\hline & $N R M S$ & 2.9693 \\
\hline \multirow[t]{4}{*}{$\frac{d P}{d t}=(\alpha \mu+\beta) X$} & $\alpha$ & 0.0091 \\
\hline & $\beta$ & 0.0090 \\
\hline & $R^{2}$ & 0.9056 \\
\hline & NRMS & 0.4484 \\
\hline
\end{tabular}

Table 4 presents a comparison of different carbon sources and $\mathrm{C} / \mathrm{N}$ ratios for microbial oil production. In this study, the biomass and oil concentrations were obtained for 22.10 and $10.99 \mathrm{~g} / \mathrm{L}$ respectively, in the flask scale experiment. The oil concentration was lower than gained by Zhu et al. (2008) using Trichosporon fermentans $(13.80 \mathrm{~g} / \mathrm{L})$, cultured in glucose $100 \mathrm{~g} / \mathrm{L}(\mathrm{C} / \mathrm{N}$ ratio $=140)$. The microbial oil production in bioreactor scale could enhance the biomass and oil production to a level higher than the flask scale and the results by Zhu $\boldsymbol{e t}$ al. (2008) and Bonturi et al. (2017). Fakas et al. (2009) studied the microbial oil production from Cunninghamella echinulate ATHUM 4411 and Mortierella isabellina ATHUM 2935, using xylose as the main carbon source with a similar $\mathrm{C} / \mathrm{N}$ ratio (285). The results exhibited variation in microbial oil production efficiency. Karamerou et al. (2016) cultured the Rhodotorula glutinis in glycero and achieved biomass and oil of 4.06 and $1.21 \mathrm{~g} / \mathrm{L}$, respectively, which led to lower oil content $(29.80 \%)$. These results showed that microbial oil production depended on the carbon source with proper $\mathrm{C} / \mathrm{N}$ ratio and the oleaginous strain.

Table 4 Studies of microbial oil production using different carbon sources and $\mathrm{C} / \mathrm{N}$ ratios

\begin{tabular}{|c|c|c|c|c|c|c|c|c|}
\hline Strains & Conditions & $\mathrm{C} / \mathrm{N}$ ratio & $\begin{array}{l}\text { Biomass } \\
(\mathrm{g} / \mathrm{L})\end{array}$ & $\begin{array}{c}\text { Oil } \\
(\mathrm{g} / \mathrm{L})\end{array}$ & $\begin{array}{l}\text { Oil content } \\
(\% \mathrm{w} / \mathrm{w})\end{array}$ & $\underset{(\mathrm{g} / \mathrm{L} h)}{Q_{\mathrm{x}}}$ & $\underset{(\mathrm{g} / \mathrm{L} h)}{Q_{\mathrm{p}}}$ & References \\
\hline $\begin{array}{l}\text { Trichosporon fermentans } \\
\text { CICC } 1368\end{array}$ & Glucose, $100 \mathrm{~g} / \mathrm{L}$ & 140 & 21.80 & 13.80 & 63.10 & $0.130^{\mathrm{a}}$ & $0.082^{\mathrm{a}}$ & $\begin{array}{c}\text { (Zhu et al., } \\
\text { 2008) }\end{array}$ \\
\hline $\begin{array}{l}\text { Cunninghamella echinulate } \\
\text { ATHUM } 4411\end{array}$ & Xylose, $80 \mathrm{~g} / \mathrm{L}$ & 285 & 7.80 & 4.50 & 57.70 & $0.041^{\mathrm{b}}$ & $0.023^{\mathrm{b}}$ & $\begin{array}{l}\text { (Fakas et } \\
\text { al., 2009) }\end{array}$ \\
\hline $\begin{array}{l}\text { Mortierella isabellina } \\
\text { ATHUM } 2935\end{array}$ & Xylose, $80 \mathrm{~g} / \mathrm{L}$ & 285 & 8.70 & 5.70 & 65.50 & $0.040^{\mathrm{c}}$ & $0.026^{\mathrm{c}}$ & $\begin{array}{l}\text { (Fakas et } \\
\text { al., 2009) }\end{array}$ \\
\hline $\begin{array}{l}\text { Rhodotorula glutinis } \\
\text { CICC } 31596\end{array}$ & Pure glycerol, $60 \mathrm{~g} / \mathrm{L}$ & 137 & 4.06 & 1.21 & 29.80 & - & - & $\begin{array}{l}\text { (Karamerou } \\
\text { et al., 2016) }\end{array}$ \\
\hline $\begin{array}{l}\text { Rhodosporidium toruloides } \\
\text { CCT } 0783\end{array}$ & Glucose, $70 \mathrm{~g} / \mathrm{L}$ & 95 & 16.50 & 7.90 & 47.90 & - & 0.083 & $\begin{array}{l}\text { (Bonturi } e t \\
a l ., 2017)\end{array}$ \\
\hline \multirow[t]{2}{*}{$\begin{array}{l}\text { P. parantarctica } \\
\text { CHC28 }\end{array}$} & Glucose (flask), $100 \mathrm{~g} / \mathrm{L}$ & 333 & 22.10 & 10.99 & 49.64 & 0.184 & 0.092 & This study \\
\hline & Glucose (bioreactor), $100 \mathrm{~g} / \mathrm{L}$ & 333 & 29.92 & 15.13 & 50.57 & 0.250 & 0.130 & This study \\
\hline
\end{tabular}

Legend: a,b,c The data were calculated with cultivation times of 168, 192, and 219 hrs, respectively; - : Information not available.

\section{CONCLUSION}

A glucose concentration composed in a nitrogen-limiting medium affected the growth and microbial oil production of $P$. parantarctica $\mathrm{CHC} 28$. The increase in glucose concentration along with the $\mathrm{C} / \mathrm{N}$ ratio enhanced biomass and oil concentration. However, the maximum specific growth rate was decreased in a high glucose concentration due to the osmotic pressure in the solution. The oil content of $50.57 \% \mathrm{w} / \mathrm{w}$ was obtained in the bioreactor. The mathematical model employed in this study could efficiently describe the experimental data in both flask and bioreactor scales. The $R^{2}$ and $N R M S$ values were higher and lower than 0.9056 and 2.9693 , respectively.

Acknowledgments: The authors are thankful to the Division of Biology, Faculty of Science and Technology, Rajamangala University of Technology Thanyaburi (RMUTT), Thailand, for providing research facilities and laboratories. The authors also gratefully acknowledge the support of RMUTT for the research scholarship.

\section{REFERENCES}

Areesirisuk, A., Chiu, C. H., Yen, S. B., \& Guo, J. H. (2015). A novel oleaginous yeast strain with high lipid productivity and its application to alternative biodiesel production. Applied Biochemistry and Microbiology, 51(4), 411-418. https://doi.org/10.1134/s0003683815030035

Beopoulos, A., Cescut, J., Haddouche, R., Uribelarrea, J.-L., Molina-Jouve, C., \& Nicaud, J.-M. (2009). Yarrowia lipolytica as a model for bio-oil production.

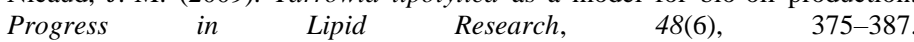
https://doi.org/10.1016/i.plipres.2009.08.005

Bligh, E. G., \& Dyer, W. J. (1959). A rapid method of total lipid extraction and purification. Canadian Journal of Biochemistry and Physiology, 37(8), 911-917. https://doi.org/10.1139/059-099

Bonturi, N., Crucello, A., Viana, A. J. C., \& Miranda, E. A. (2017). Microbial oil production in sugarcane bagasse hemicellulosic hydrolysate without nutrient supplementation by a Rhodosporidium toruloides adapted strain. Process Biochemistry, 57, 16-25. https://doi.org/10.1016/j.procbio.2017.03.007 
Fakas, S., Papanikolaou, S., Batsos, A., Galiotou-Panayotou, M., Mallouchos, A., \& Aggelis, G. (2009). Evaluating renewable carbon sources as substrates for single cell oil production by Cunninghamella echinulata and Mortierella isabellina. Biomass and Bioenergy, 33(4), 573-580. https://doi.org/10.1016/j.biombioe.2008.09.006

Farias, D., Andrade, R. R. de, \& Maugeri-Filho, F. (2014). Kinetic modeling of ethanol production by Scheffersomyces stipitis from xylose. Applied Biochemistry and Biotechnology, 172(1), 361-379. https://doi.org/10.1007/s12010-013-0546-y Gaden, E. L. (2000). Fermentation process kinetics. Reprinted from Journal of Biochemical Microbiological Technology and Engineering Vol. 1, No. 4 Pages 413-29 (1959). Biotechnology and Bioengineering, 67(6), 629-635.

Gill, C. O., Hall, M. J., \& Ratledge, C. (1977). Lipid accumulation in an oleaginous yeast (Candida 107) growing on glucose in single-stage continuous culture. Applied and Environmental Microbiology, 33(2), 231-239. https://doi.org/10.1128/aem.33.2.231-239.1977

Granger, L.-M., Perlot, P., Goma, G., \& Pareilleux, A. (1993). Effect of various nutrient limitations on fatty acid production by Rhodotorula glutinis. Applied $\begin{array}{llll}\text { Microbiology and } \quad \text { Biotechnology, 38(6), } & \text { 784-789. }\end{array}$ https://doi.org/10.1007/BF00167145

Huang, X.-F., Liu, J.-N., Lu, L.-J., Peng, K.-M., Yang, G.-X., \& Liu, J. (2016). Culture strategies for lipid production using acetic acid as sole carbon source by Rhodosporidium toruloides. Bioresource Technology, 206, 141-149. https://doi.org/10.1016/j.biortech.2016.01.073

Jakobsen, A. N., Aasen, I. M., Josefsen, K. D., \& Strøm, A. R. (2008) Accumulation of docosahexaenoic acid-rich lipid in thraustochytrid Aurantiochytrium sp. strain T66: Effects of $\mathrm{N}$ and $\mathrm{P}$ starvation and $\mathrm{O}_{2}$ limitation. Applied Microbiology and Biotechnology, 80(2), 297. https://doi.org/10.1007/s00253-008-1537-8

Karamerou, E. E., Theodoropoulos, C., \& Webb, C. (2016). A biorefinery approach to microbial oil production from glycerol by Rhodotorula glutinis. $\begin{array}{llll}\text { Biomass } \quad \text { and } & \text { Bioenergy, } & \text { 113-122. }\end{array}$ https://doi.org/10.1016/j.biombioe.2016.01.007

Laopaiboon, L., Phukoetphim, N., \& Laopaiboon, P. (2016). Logistic function and modified Gompertz models for batch ethanol fermentation kinetics from sweet sorghum juice under high gravity condition. New Biotechnology, 33, S86S87. https://doi.org/10.1016/j.nbt.2016.06.1019

Li, Y., Zhao, Z. (Kent), \& Bai, F. (2007). High-density cultivation of oleaginous yeast Rhodosporidium toruloides Y4 in fed-batch culture. Enzyme and Microbia Technology, 41(3), 312-317. https://doi.org/10.1016/j.enzmictec.2007.02.008

Ma, X., Gao, Z., Gao, M., Ma, Y., Ma, H., Zhang, M., Liu, Y., \& Wang, Q. (2018). Microbial lipid production from food waste saccharified liquid and the effects of compositions. Energy Conversion and Management, 172, 306-315. https://doi.org/10.1016/j.enconman.2018.07.005

Marudkla, J., Lee, W.-C., Wannawilai, S., Chisti, Y., \& Sirisansaneeyakul, S. (2018). Model of acetic acid-affected growth and poly(3-hydroxybutyrate) production by Cupriavidus necator DSM 545. Journal of Biotechnology, 268 12-20. https://doi.org/10.1016/j.jbiotec.2018.01.004

Miller, G. L. (1959). Use of dinitrosalicylic acid reagent for determination of reducing sugar. Analytical Chemistry, 31(3), 426-428 https://doi.org/10.1021/ac60147a030

Ong, H. C., Mahlia, T. M. I., Masjuki, H. H., \& Norhasyima, R. S. (2011). Comparison of palm oil, Jatropha curcas and Calophyllum inophyllum for biodiesel: A review. Renewable and Sustainable Energy Reviews, 15(8), 35013515. https://doi.org/10.1016/j.rser.2011.05.005

Phukoetphim, N., Salakkam, A., Laopaiboon, P., \& Laopaiboon, L. (2017). Kinetic models for batch ethanol production from sweet sorghum juice under normal and high gravity fermentations: Logistic and modified Gompertz models.
Journal
of Biotechnology,
243
69-75. https://doi.org/10.1016/j.jbiotec.2016.12.012

Qasim, W. S., \& Sultan, R. H. (2020). Production of single cell oil from local isolates Rhodotorula glutinis. Journal of Microbiology, Biotechnology and Food Sciences, 10(2), 279-283. https://doi.org/10.15414/jmbfs.2020.10.2.279-283

Qin, L., Liu, L., Zeng, A.-P., \& Wei, D. (2017). From low-cost substrates to single cell oils synthesized by oleaginous yeasts. Bioresource Technology, 245 1507-1519. https://doi.org/10.1016/j.biortech.2017.05.163

Ratledge, C., \& Wynn, J. P. (2002). The biochemistry and molecular biology of lipid accumulation in oleaginous microorganisms. Advances in Applied Microbiology, 51, 1-51. https://doi.org/10.1016/s0065-2164(02)51000-5

Saenge, C., Cheirsilp, B., Suksaroge, T. T., \& Bourtoom, T. (2011). Potential use of oleaginous red yeast Rhodotorula glutinis for the bioconversion of crude glycerol from biodiesel plant to lipids and carotenoids. Process Biochemistry, 46(1), 210-218. https://doi.org/10.1016/j.procbio.2010.08.009

Satyanarayana, M., \& Muraleedharan, C. (2011). A comparative study of vegetable oil methyl esters (biodiesels). Energy, 36(4), 2129-2137. https://doi.org/10.1016/j.energy.2010.09.050

Soccol, C. R., Dalmas Neto, C. J., Soccol, V. T., Sydney, E. B., da Costa, E. S. F., Medeiros, A. B. P., \& Vandenberghe, L. P. de S. (2017). Pilot scale biodiesel production from microbial oil of Rhodosporidium toruloides DEBB 5533 using sugarcane juice: Performance in diesel engine and preliminary economic study.
Bioresource

Technology,

223 ,

$259-268$

https://doi.org/10.1016/j.biortech.2016.10.055

Sutanto, S., Zullaikah, S., Tran-Nguyen, P. L., Ismadji, S., \& Ju, Y.-H. (2018) Lipomyces starkeyi: Its current status as a potential oil producer. Fuel Processing Technology, 177, 39-55. https://doi.org/10.1016/j.fuproc.2018.04.012

Tai, M., \& Stephanopoulos, G. (2013). Engineering the push and pull of lipid biosynthesis in oleaginous yeast Yarrowia lipolytica for biofuel production. Metabolic Engineering, 15, 1-9. https://doi.org/10.1016/j.ymben.2012.08.007

Wannawilai, S., \& Sirisansaneeyakul, S. (2015). Economical production of xylitol from Candida magnoliae TISTR 5663 using sugarcane bagasse hydrolysate. Kasetsart Journal - Natural Science, 49, 583-596.

Wu, S., Hu, C., Jin, G., Zhao, X., \& Zhao, Z. K. (2010). Phosphate-limitation mediated lipid production by Rhodosporidium toruloides. Bioresource Technology, 101(15), 6124-6129. https://doi.org/10.1016/j.biortech.2010.02.111 Wu, S., Zhao, X., Shen, H., Wang, Q., \& Zhao, Z. K. (2011). Microbial lipid production by Rhodosporidium toruloides under sulfate-limited conditions. Bioresource $\quad$ Technology, 102(2), 1803-1807. https://doi.org/10.1016/j.biortech.2010.09.033

Xue, F., Miao, J., Zhang, X., Luo, H., \& Tan, T. (2008). Studies on lipid production by Rhodotorula glutinis fermentation using monosodium glutamate wastewater as culture medium. Bioresource Technology, 99(13), 5923-5927. https://doi.org/10.1016/j.biortech.2007.04.046

Yang, J., Rasa, E., Tantayotai, P., Scow, K. M., Yuan, H., \& Hristova, K. R. (2011). Mathematical model of Chlorella minutissima UTEX2341 growth and lipid production under photoheterotrophic fermentation conditions. Bioresource Technology, 102(3), 3077-3082. https://doi.org/10.1016/j.biortech.2010.10.049 Yen, H.-W., \& Liu, Y. X. (2014). Application of airlift bioreactor for the cultivation of aerobic oleaginous yeast Rhodotorula glutinis with different aeration rates. Journal of Bioscience and Bioengineering, 118(2), 195-198 https://doi.org/10.1016/i.jbiosc.2014.01.002

Yen, H.-W., \& Zhang, Z. (2011). Effects of dissolved oxygen level on cell growth and total lipid accumulation in the cultivation of Rhodotorula glutinis Journal of Bioscience and Bioengineering, 112(1), 71-74. https://doi.org/10.1016/j.jbiosc.2011.03.013

Zajšek, K., \& Goršek, A. (2010). Modelling of batch kefir fermentation kinetics for ethanol production by mixed natural microflora. Food and Bioproducts Processing, 88(1), 55-60. https://doi.org/10.1016/j.fbp.2009.09.002

Zhu, L. Y., Zong, M. H., \& Wu, H. (2008). Efficient lipid production with Trichosporon fermentans and its use for biodiesel preparation. Bioresource Technology, 99(16), 7881-7885. https://doi.org/10.1016/j.biortech.2008.02.033 